\title{
Complesto
}

\section{Reflexões sobre o Museu de Arte Popular do Instituto Feminino da Bahia}

\author{
Marcelo Nascimento Bernardo da Cunha \\ Doutor; Universidade Federal da Bahia, Salvador, BA, Brasil; \\ marcelo.bernardodacunha.cunha@gmail.com \\ Suely Moraes Cerávolo \\ Doutora; Universidade Federal da Bahia, Salvador, BA, Brasil; \\ sumocem@gmail.com
}

\begin{abstract}
Resumo: As reflexões sobre o Museu de Arte Popular do Instituto Feminino da Bahia (IFB), escola para mulheres que marcou época na cidade do Salvador das primeiras décadas a meados do século XX, objetivam destacar aspectos ainda não explorados sobre a relação entre a edificação e a estrutura expográfica com a Coleção de Arte Popular dessa instituição baiana. Com base em pesquisa documental procura-se correlacionar as fontes consultadas, de modo a recompor o trajeto de formação de coleção para museu e descrever as características do espaço destinado a abrigar o acervo a partir de 1939 e os equipamentos e modos expositivos, concluindo-se sobre a importância e necessidade de mais pesquisas para desvendar as camadas de historiografia que ultrapassam a do próprio IFB.
\end{abstract}

Palavras-chave: Museu de Arte Popular do Instituto Feminino da Bahia. Coleção. Espaço expositivo.

\section{Sobre a abordagem analítica para o Museu de Arte Popular do Instituto}

\section{Feminino da Bahia (IFB): uma questão de fontes de pesquisa}

Este texto surge de reflexões realizadas por nós no âmbito de investigações desenvolvidas no Grupo de Pesquisa Observatório da Museologia na Bahia (CNPq/Universidade Federal da Bahia), identificando estratégias, protagonismos e ações específicas com o fim de compreender criticamente os processos de patrimonialização e musealização ocorridos na cidade do Salvador, visando o entendimento do que chamamos campo museológico dessa cidade.

Ao longo dos anos vão se revelando a articulação de indivíduos, propostas e concepções sobre o patrimônio e sua utilização, ao evidenciar e analisar determinadas recorrências ao tempo em que se procura captar a 
manutenção ou mudanças de aspectos singulares nesse campo específico de estudos, o que inclui abordagens ideológicas e interpretativas a respeito das práticas culturais preservacionistas. Os estudos iniciam pela aproximação com as instituições investigadas através da visita às suas exposições (quando ainda em funcionamento), paralelamente à busca por documentação administrativa, histórica e museológica que possam dar pistas para o entendimento sobre prováveis origens, trajetórias, formação de coleções, exposições e ações desenvolvidas. Igualmente faz parte da abordagem a localização de estudos acadêmicos anteriores sobre as instituições bem como o contexto histórico social aos quais estão relacionadas, para o que interessam publicações em veículos noticiosos, como jornais e revistas.

Os resultados alcançados nesse processo de construção de relatos sobre memórias institucionais são diversos ficando patente que, as conclusões, serão sempre passiveis de complementação e, até mesmo, contestação, considerandose que, muitas vezes, e pincipalmente sobre determinados aspectos, as informações se apresentam fragmentadas, carecendo de um corpo documental maior para um entendimento amplo do contexto institucional. Nesse quadro desponta uma questão que se revela a quem investiga memórias de instituições museológicas: a ausente e contraditória fragilidade memorialística justo nos lugares voltados à preservação de memórias. Importante destacar que muitos são os fatores que levam a isso, relacionados às mais diversas conjunturas - de recursos humanos, as materiais e tecnológicas e, mesmo, as conceituais. Com efeito, a complexidade dos processos museológicos implica uma série de ações nem sempre fáceis de controlar e registrar a ponto de contar, posteriormente, com a possibilidade de recuperar gêneses e transformações processuais.

No caso do Museu de Arte Popular do Instituto Feminino da Bahia (IFB), desde anos atrás estabelecemos algum tipo de estratégia de abordagem, sendo a mais recorrente, até esse momento, a identificação e recolha de notícias veiculadas ao longo de décadas de extrema importância para entender a conjuntura institucional, considerando que este museu compõe uma estrutura museológica e organizacional mais ampla. Para complementar as notícias recorre-se a outros escritos como publicações, dissertações e teses, opúsculos 
editados pelo próprio Instituto dentre outras fontes possíveis de serem consultadas que vão elucidando circunstâncias de época e revelando - aqui ou ali - traços de Dona Henriqueta Catharino ${ }^{1}$, a mentora da instituição. Supõe-se que há ainda um corpo documental a ser abordado - notadamente escritos e registros de próprio punho de Henriqueta Martins Catharino - relativos ao colecionismo e ao cotidiano institucional que esclareçam as ações, no presente foco, em particular sobre a formação do acervo do popular. A existência dessas referências é uma hipótese plausível sustentada por algumas pistas e informações, porém, uma série de circunstâncias impossibilitou, até o momento, o contato com tais fontes. Já no que diz respeito à exposição propriamente dita, fazia parte de nossa proposta apresentar considerações mais detalhadas sobre como a exposição se encontra atualmente. Não obstante a intenção de complementar as visitas técnicas realizadas anteriormente, nos vimos sem condições de realizá-las em virtude da pandemia e decretação do estado de emergência e isolamento social imposto pela Covid-19.

Ainda que conscientes da necessidade de ampliação da investigação para que sejam desveladas novas questões relativas a esse museu, para os autores, a escrita deste ensaio se justifica como recurso para evidenciar a importância da Coleção de Arte Popular do IFB, entendida como importante documento relativo ao colecionismo de início do século XX e sua relação à concepção de cultura e patrimônio vigente naquele momento, possibilitando inclusive refletir sobre os contínuos que se apresentam na atualidade.

Uma vez explicitada a abordagem analítica e a questão de fontes de pesquisa sobre o Museu de Arte Popular do Instituto Feminino da Bahia (IFB), nosso objetivo aqui é o de correlacionar as fontes consultadas para recompor o trajeto de formação daquilo que se iniciou como um apanhado de objetos, avolumando-se a ponto de compor uma coleção específica e farta e desta para museu. Procuramos salientar aspectos ainda não explorados entre a relação da edificação e a estrutura expográfica e a Coleção de Arte Popular dessa referida instituição, procurando descrever as características do espaço destinado a abrigar o acervo a partir de 1939, os equipamentos e modos expositivos para então chegarmos às considerações finais. 


\section{O Museu de Arte Popular}

O Museu de Arte Popular é um dos segmentos do Museu Henriqueta Catharino formado por outras duas divisões: a de artes decorativas (Museu Henriqueta Catharino), e a de têxtil (Museu do Traje e do Têxtil, todas resultantes do colecionismo de Henriqueta Catharino. Guiada pela moral cristã, Dona Henriqueta, como chamada, conduziu programas assistencialistas e para a educação e profissionalização de mulheres a partir da década de 1920 na cidade do Salvador, com apoio pleno da Igreja católica e da elite baiana (PASSOS, 1993, 2010). Oficializado como órgão de utilidade pública em 21 de março de 1929, o Instituto Feminino da Bahia (IFB), dedicou-se à educação e desenvolvimento das mulheres. A arte, a música e a poesia sob a influência do Romantismo fizeram parte dos interesses de Dona Henriqueta, assim como viagens à Europa - França em particular - trazendo na bagagem objetos de arte e curiosidades. Além de participar de bazares e leilões, não se furtava a recorrer à empréstimos junto a seu ao círculo de amizades ou doações de famílias abastadas - mulheres na maioria - para complementar as exposições temporárias no IFB (QUEIRÓZ, 2016).

Se o argumento para formar os conjuntos de artes decorativas e indumentárias associava-se à intenção de apresentar para as alunas os costumes das tradicionais elites baianas do passado, o de arte popular justificava-se pela representatividade das culturas nacional e baiana (PASSOS, 1993). Nesse aspecto, e pelo período em que começou a atuar, início dos anos 20, não se descarta a notória expressão identitária nacionalista e regional que condiz, no discurso, com a ideia de Brasil unido das primeiras décadas da_República. As elites da Bahia, nesse período, viviam dialéticas tensões simbólicas entre a importância que detivera ao longo do Império, reconhecida pelos talentos e centralidade política, e o esforço em recobrá-las. Reviver o lugar emblemático do passado era fonte de inspiração identitária e, nessa conjuntura geral, o povo, “objeto pedagógico", carregava a "essência” de um passado ainda cercado pelos poderes totalizantes, a quem interessava presentificá-lo, confirmando o próprio discurso das elites (LEITE, 2012, p. 29-30; grifo nosso). 
Em relação ao colecionismo do popular, quer de particulares quer do Estado $^{2}$, ajudava a sedimentar a defesa de tradições e, simultaneamente, impulsionava a sua legitimação (SANTOS, 2013). A despeito da argumentação do IFB em tom preservacionista das tradições das elites ou do popular, consideramos que Henriqueta Catharino foi movida por dois movimentos complementares: de um lado pela filosofia de vida caritativa determinada a ajudar o próximo e daí o adquirir ou ganhar artefatos populares e, por outro, pela paixão colecionista (CERÁVOLO, 2020).

Pensando-se na perspectiva material e expográfica, é preciso ter em mente que, longe de simples apresentação, ali estão reunidos conceitos propositivos, discursos, narrativas, preservação de referências (políticas, históricas, de dinâmicas culturais e patrimoniais), formulando espaço de manejo ideológico e inclusive a afirmação de valores morais (CUNHA, 2006). Compreender o universo ideológico e a conjuntura social dos quais colecionadora fez parte, ajuda a entender as exposições que, sob determinado ângulo, a revelam e à certa mentalidade da sua época. Com esses traços, seguimos adiante para refletir sobre a exposição do Museu de Arte Popular do IFB, abordando características da edificação para situar o espaço no qual ficou alojado e perceber a exposição em relação ao conjunto do qual faz parte.

\section{A edificação e a estrutura expográfica do Museu Arte Popular do IFB}

Museus são conhecidos, acima de tudo, pelas salas de exposições. Segundo os autores de Conceitos-Chave em Museologia (DESVALLÉES; MAIRESSE, 2013), a palavra exposição remete à ação ou ao conjunto do que é exposto, mais o lugar (o espaço propriamente dito) no qual aquele agregado está dado a ver para visitantes. Seguindo o verbete, mas, procurando interpretá-lo, o espaço expositivo pretende proporcionar ao visitante a vivência sensível advinda da experiência individual, ao tempo em que mobiliza graus de interações sociais e culturais (sujeito/objeto; sujeito/assunto; sujeito/sujeito e assim por diante), perfazendo um composto aberto de relações interativas. As coisas, originais ou não, colocadas em vitrines, elementos de separação, ou mesmo sem esses aparatos, como que operam entre dois universos: o material, concreto, e o 
imaginário e imaginado. Nessa linha, continuam os autores do verbete, uma vez que a realidade não pode ser transferida para um museu, a exposição que ali acontece leva o sujeito a recorrer a analogias em dinâmico processo semiológico de comunicação. Vale adicionar que, a nosso ver, o Museu faz lembrar ainda que seletivamente os

\begin{abstract}
elementos da cultura, costumes, crenças, valores, hábitos, pessoas, grupos e acontecimentos ajudando na definição de quais elementos identificam e diferenciam os grupos e suas práticas sociais, relacionando determinados objetos a imagens sociais de grupos sociais, inventando tradições. Pode ser elemento através do qual imagens e objetos, fabricam uma imagem "ideal" da realidade e suas dimensões. Por outro lado, museus também podem promover os esquecimentos, na medida em que, ao selecionar determinados elementos para compor o quadro das referências, deixa uma grande quantidade de outros elementos de fora de suas coleções e alheios a seus significados. (CUNHA, 2006, p.15)
\end{abstract}

Segundo Bernard Deloche, ao discorrer sobre as mitologias e o plano semiológico que cercam os museus, organismos culturais que se reapropriam do simbólico naturalizando sistemas de valores, os "expôts" - todo objeto suscetível de ser exposto - na condição de signos, assumem a posição de "unidades discretas", indissociáveis umas das outras, formando os elementos componentes de uma espécie de frase mais ou menos elaborada (nível denotativo), aproveitados na exposição (o texto) como "dispositivo[s] de comunicação e produção de sentido" operando no nível retórico (conotação), perspectiva analítica que faz a equivalência entre exposição e discurso (DELOCHE, 2010, p. 22-41). Vale ressaltar que, na condição de texto, as exposições são construídas com elementos diversos e sinais distintivos, além da composição de ritmo, a de gramática e sintaxe que, ao se articularem, permitem perceber "ênfases, proposições, metáforas" em leitura não uniforme na dependência do grau e nível de interação de cada indivíduo com o tema e os elementos que se apresentam (CUNHA, 2010, p.110).

Outra ponderação de Deloche (2010) de interesse para o assunto aqui tratado, diz respeito à ucronia (uchronie), algo intrínseco aos museus, referindose à história apócrifa, atemporal, colocada a serviço da ideologia com força para realizar a adesão dos membros de um grupo, assim e ao mesmo tempo, dando corpo a ideias e convicções às quais estão inerentemente unidos. Ao que se 
conclui que museus e exposições em museus tendem a transformar conteúdos em impulso performativo - que se pode dizer estruturante - para direcionar modos de ver o mundo (quando não em dogmas e regras).

Após essas breves considerações sobre o ato de expor que ajudam a demarcar nossa perspectiva sobre a abordagem expográfica, considerada como arranjo, voltamos ao Museu de Arte Popular e sua sede.

Antes de 1939, ano de inauguração da sede na qual o museu se encontra até hoje alojado, Henriqueta Catharino e o Monsenhor Flaviano Osório Pimentel $^{3}$, criaram a Casa São Vicente, em 1923,_no Terreiro de Jesus (Praça 15 de Novembro, Centro Histórico) e, dentre os serviços programados ${ }^{4}$, a Escola Comercial Feminina para a formação profissional e moral no escopo da educação católica. Em 1924 foi transferida para imóvel herdado na Praça da Piedade; em 1928 para a Avenida Sete de Setembro (no. 215, nas proximidades do Rosário $)^{5}$. No ano seguinte, já como Instituto Feminino da Bahia, foi reconhecido de utilidade pública, como assinalado anteriormente ${ }^{6}$ e, depois, Fundação Instituto Feminino da Bahia em 1950 (PASSOS, 2010). As sucessivas mudanças de imóvel sinalizam para a ampliação e consolidação dos projetos assistencialistas e educativos que funcionavam em paralelo, requerendo, cada vez mais, espaços maiores de acomodação e, consequentemente, adaptação às instalações. Acomodações que, para o presente foco analítico, dizem respeito às coleções que se ampliavam no trajeto. Exemplo do uso sobreposto de espaços se tem na imagem fotográfica da edição especial do $O$ Imparcial (1934), em que podemos observar móveis repletos de objetos e servindo de aparador para outros tantos, bem como nas paredes ${ }^{7}$. Na legenda, constata-se a junção do gabinete de ciências físicas e naturais e museu em uma mesma sala (Figura 1). 
Figura 1 - Gabinete de Ciêncas Naturais e Museu do IFB - Edifício da Av. Sete de Setembro

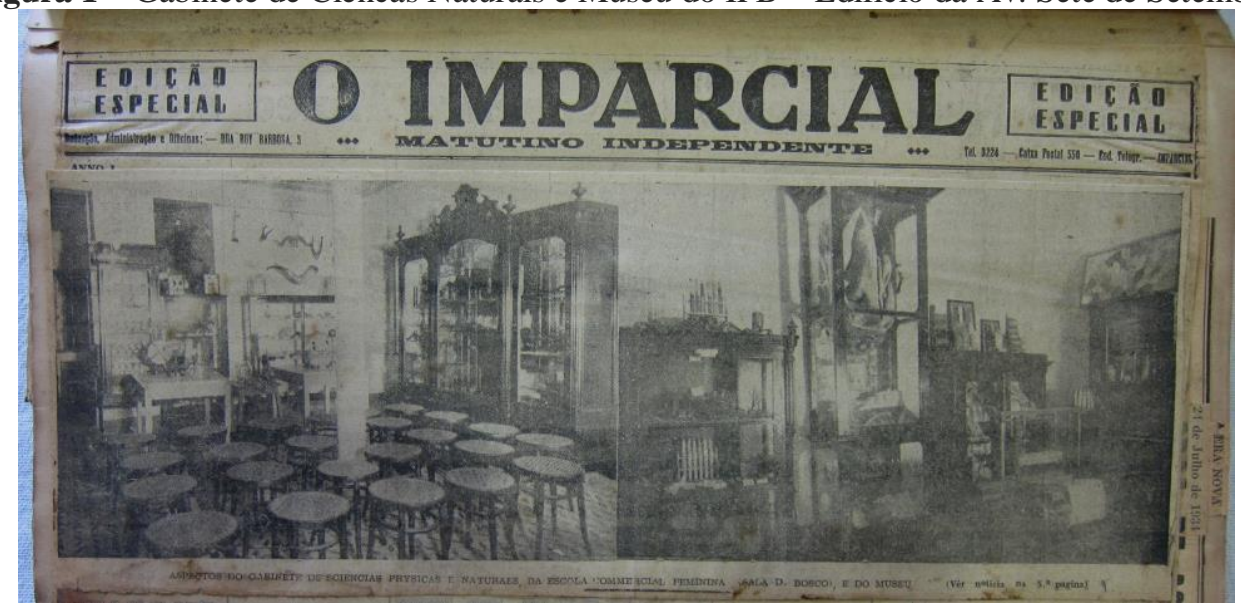

Fonte: Jornal O Imparcial (1934).

Nota: "Aspectos do Gabinete de sicencias physicas e naturais da Escola Commercial Feminina (Sala d. Bosco e do Museu)" O Imparcial - Edição Especial, 1934. Álbum Recordando, IFB ${ }^{8}$. Observar no primeiro plano, várias banquetas, provavelmente para aulas e duas pequenas mesas.

Os projetos de Henriqueta Catharino se expandiram e, com herança recebida, ela investiu na construção da sede própria iniciada em 1937 e finalizada em 1939, com 5mil m² de área construída (PEIXOTO, 2003), com aspecto de "solar de família" (PASSOS, 1993, p. 27). Edifício de "linhas severas" seguindo "[...] rigorosas condições hygienicas de cubagem, claridade etc [...]" (Figura 2), começou a funcionar abrigando cursos profisssionalizantes antes mesmo de findar os detalhes, como informado em jornal da época, ao divulgar que "Embora não innaugurado oficialmente já está funccionando no seu novo edifício o Instituto Feminino"" (JORNAL A TARDE, 1939, não paginada).

Figura 2 - IFB no final da construção em 1939

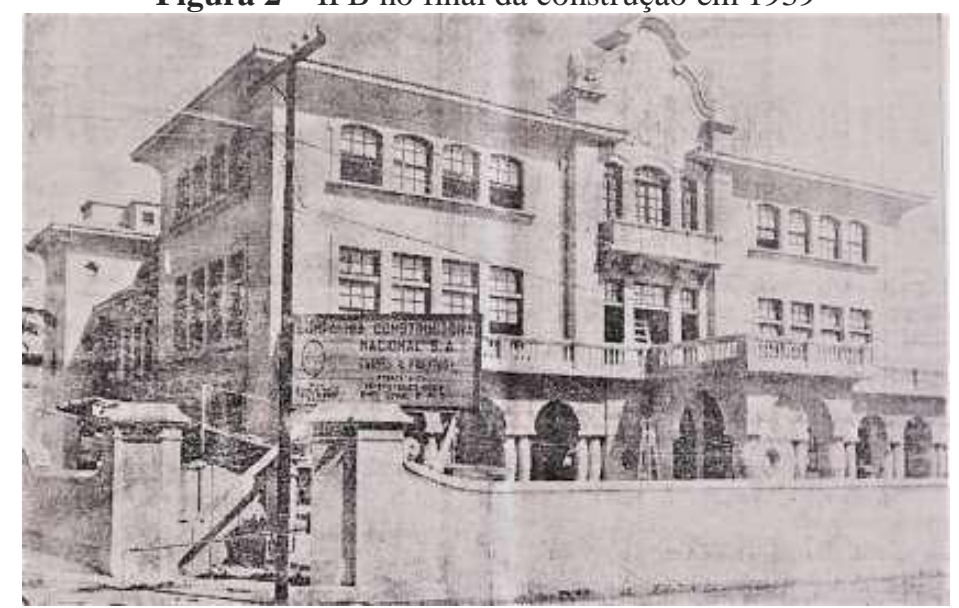

Fonte: Souza (2017, p. 128).

Em Questão, Porto Alegre, v. 26, p. 206-234, Edição Especial Dossiê Patrimônio e Culturas Tradicionais, 2020 | 213 doi: http://dx.doi.org/10.19132/1808-5245260.206-234 
Na sede planejada estava prevista a "Sala Museu" assim denominada por Henriqueta Catharino, com $120 \mathrm{~m}^{2}$, instalada no mesmo piso das salas de aula, e a capela (PEIXOTO, 2003, p. 11) ${ }^{10}$, guarnecida com vitrines e mostruários (PASSOS, 1993). Há uma ressalva: apesar de existir uma sala para museu, Ana Lucia U. Peixoto informa que, toda a instituição era decorada com "móveis, porcelanas, biscuits, opalinas" (PEIXOTO, 2003, p. 11), dentre outros objetos de arte decorativa, o que demarca a "ocupação esmerada" a que se refere Elizete Silva Passos (1993, p. 27), com peças em uso e ou decoração que se destacam aos olhos de qualquer visitante, sendo, ainda hoje, a ambiência interna ao prédio. Além disso, identifica-se a criação de uma segunda sala de exposição (no mesmo pavimento), aberta em 1940 por Henriqueta Catharino para expor a coleção de roupas, guarnecida com vitrines e mostruários apropriados, encomendados em firma especializada (PEIXOTO, 2003).

A notar que, a escolha de lugar, espaço e recursos expositivos mobiliário, iluminação, acervo e outras variáveis - ultrapassam o acaso. Ao contrário, em se pensando na estrutura expográfica são vetores fundantes e mecanismos articuladores do discurso constituído por uma instituição, refletidos em projeções para os visitantes (CUNHA, 2006).

O espaço impõe uma lógica: a do seu próprio sentido arquitetônico, que se aplica a grandes estruturas arquitetônicas ou, igualmente, nas construções que passam despercebidas, pois marcadas por determinadas linguagens formadoras do "discurso do arranjo espacial" (COELHO NETTO, 1999, p. 11), mas cujo sentido pode ser modificado, ou seja, semantizado ou dessemantizado. Abordagem que pode ser realizada articulando nexos entre o espaço interior e o exterior, o privado e o comum, o construído e não construído, artificial e natural, amplo ou restrito, vertical ou horizontal, geométrico ou não, ainda na análise desse mesmo autor e obra. Em se pensando na comunicação os objetos, no caso dos museus em que vão integrar determinado espaço, este, por seu turno, os redefine em vínculos indissociáveis e solidários, fator que altera o fluxo dos sentidos (DOHMAN, 2013).

Justamente por considerar esses vetores para análise do espaço versus estrutura expográfica se destaca a localização das exposições dos museus do 
IFB, em diferentes pavimentos (no $1^{\circ}$. o Museu Henriqueta Catharino; no $2^{\circ}$. o do Traje e do Têxtil, no subsolo, o de Arte Popular), pois modelam a própria ambiência para a fruição dos objetos e criam microcosmos no interior mesmo da instituição, influenciados pelo valor simbólico que pode ser atribuído a cada um desses pavimentos.

O edifício do IFB na análise da arquiteta Mariella Araújo de Souza foi construído, em termos estruturais, em concreto armado ${ }^{11}$, condizente com a "política tradicionalista [do Estado da Bahia]" (SOUZA, 2017, p. 118-127), de acordo com o movimento neocolonial de inspiração portuguesa das décadas de 1920-1940 e o pensar elitista burguês da época. A imponente fachada do edifício marcou fortemente a existência do IFB na cidade do Salvador e serviu, durante anos seguidos, como ilustração para as muitas reportagens publicadas em jornais chamando atenção ora para o Museu de Arte Feminina ${ }^{12}$, ora para cerimônias, exposições e festejos ali realizados, mesmo passados 25 anos de atividades ${ }^{13}$.

Dos cinco pavimentos (térreo, $1^{\circ}, 2^{\circ} .3^{\circ}$ e $\left.4^{\circ}\right)^{14}$, o definido como térreo (Figura 3) em planta baixa (de 1956) era ocupado pelas “áreas de esporte e lazer", com acesso pelo lado posterior (SOUZA, 2017, p.128-129) ${ }^{15}$.

Figura 3 - Planta baixa do Pavimento Térreo que corresponde ao subsolo da edificação do IFB;

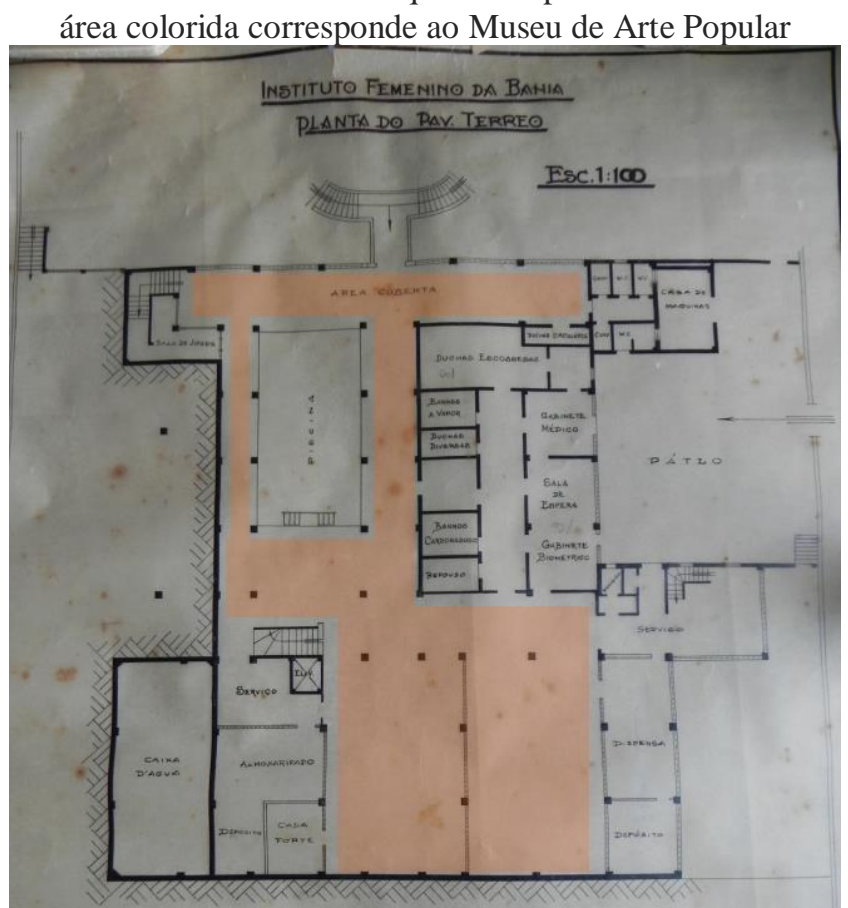

Fonte: Souza (2020).

Nota: indicação da área em cor realizada por Ainá C. Calia. 
Nesse pavimento, em parte da área construída foi instalado o Museu de Arte Popular (e ali continua), e a mostra do acervo entre os vãos livres delimitados por vigas e pilares de concreto (Figura 4), ocupando ampla área do pavimento $^{16}$, igualmente compartimentado em salas de funções definidas, tal como nos outros andares ${ }^{17}$. A piscina, depois esvaziada, servia para aulas de natação das alunas, preparando-as para competições ${ }^{18}$, em época em que a concepção de lazer para o IFB associava-se aos imperativos da formação moral católica em uma cidade do Salvador que vivia - no pano de fundo e em relação às mulheres - a tensão entre o tradicional e o novo (PASSOS, 1993).

Figura 4 - Destaque para as vigas e pilares em concreto da parte ocupada pela exposição do

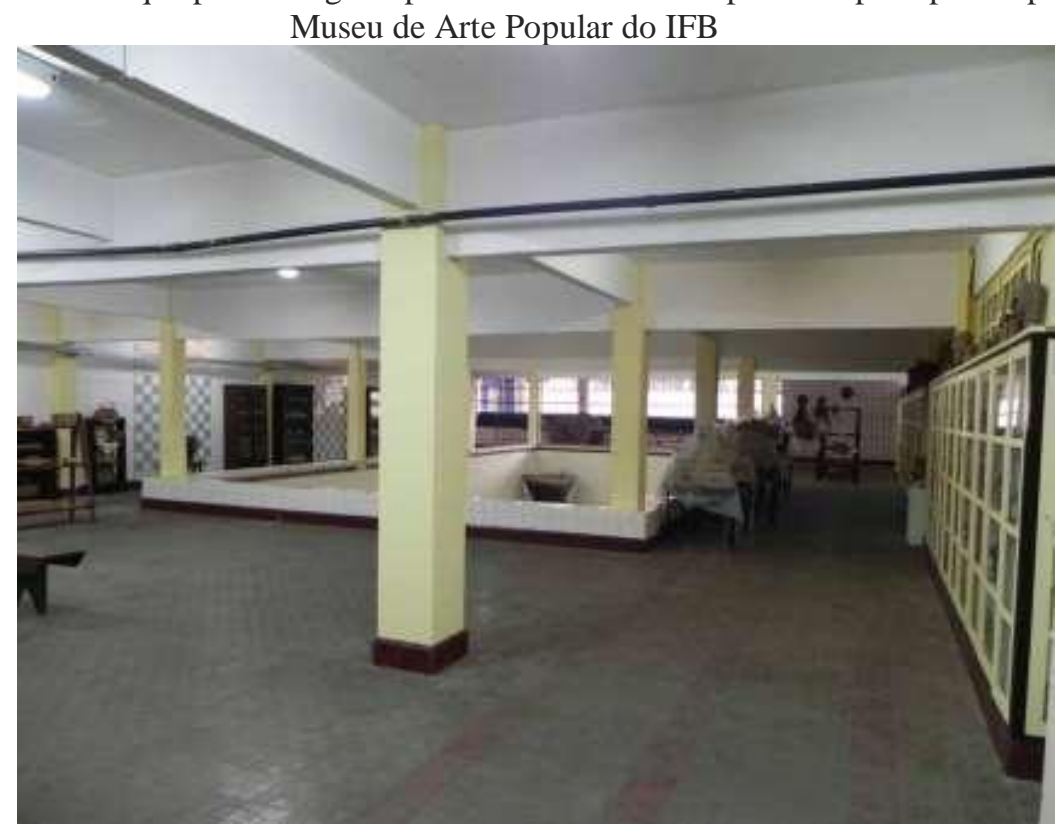

Fonte: Souza (2017, p. 139).

Nota: Primeiro plano as vigas e pilares; em segundo plano a piscina vazia, ladeada por corredores e a área coberta ao fundo ocupada por expositores. Observar à direita a prolongada estante envidraçada com a parte superior também servindo de expositor.

Com acesso interno através de escadas e pouca iluminação e aeração natural, a área destinada para essa exposição foi equipada com suportes expositivos de diferentes feitios, dimensões e qualidade do material. Há estantes e algumas prateleiras alinhadas às paredes, possivelmente executadas sob medida, e nichos inclusos na alvenaria. Outros são móveis (em madeira) reaproveitados como expositores: cristaleiras, étagères ${ }^{19}$, aparadores, bases, cavaletes, banquetas. Junto às paredes, refletem o aproveitamento do espaço disponível ou quando em separado ressaltam a peça que se pretendia apresentar. 
Há expositores que parecem encomendados, como o mobiliário de dupla face envidraçada possibilitando a visão de todos os ângulos, e réplicas em madeira idênticas à do Museu de Arte Popular de Portugal (Figuras 5 a 9). Salvo alguma mudança ao longo do tempo infere-se que se mantenha o mesmo ordenamento até hoje.

Figura 5 - Equipamento expositivo: estantes paralelas à parede - Museu de Arte Popular IFB

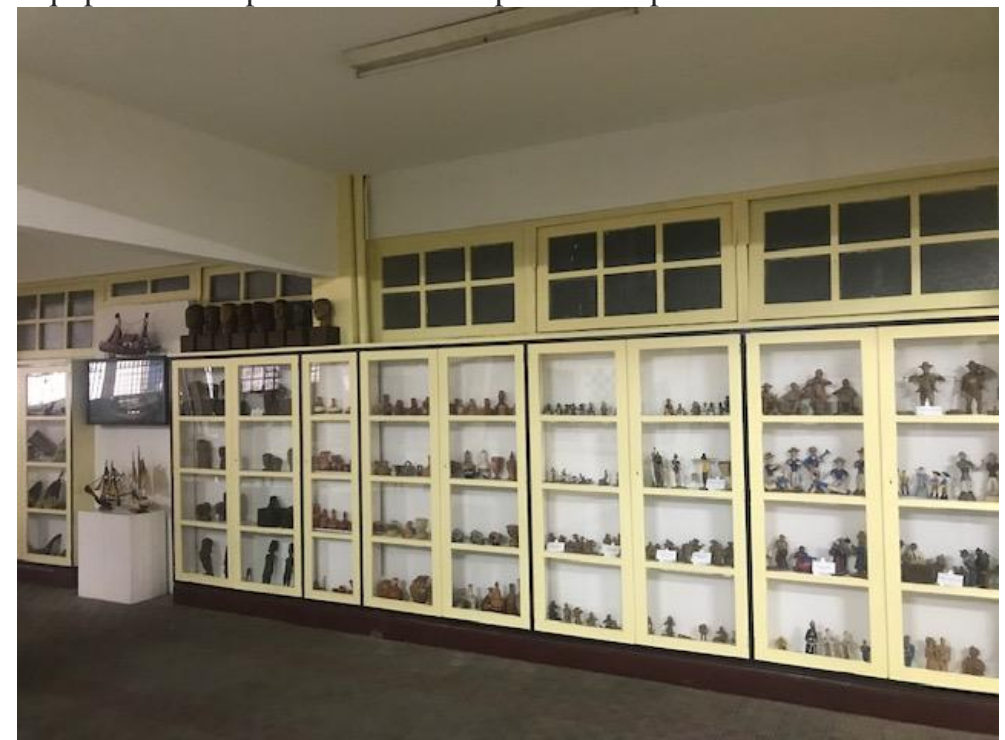

Foto: Castro (2018).

Figura 6 - Museu de Arte Popular IFB - exemplos de móveis domésticos utilizados como

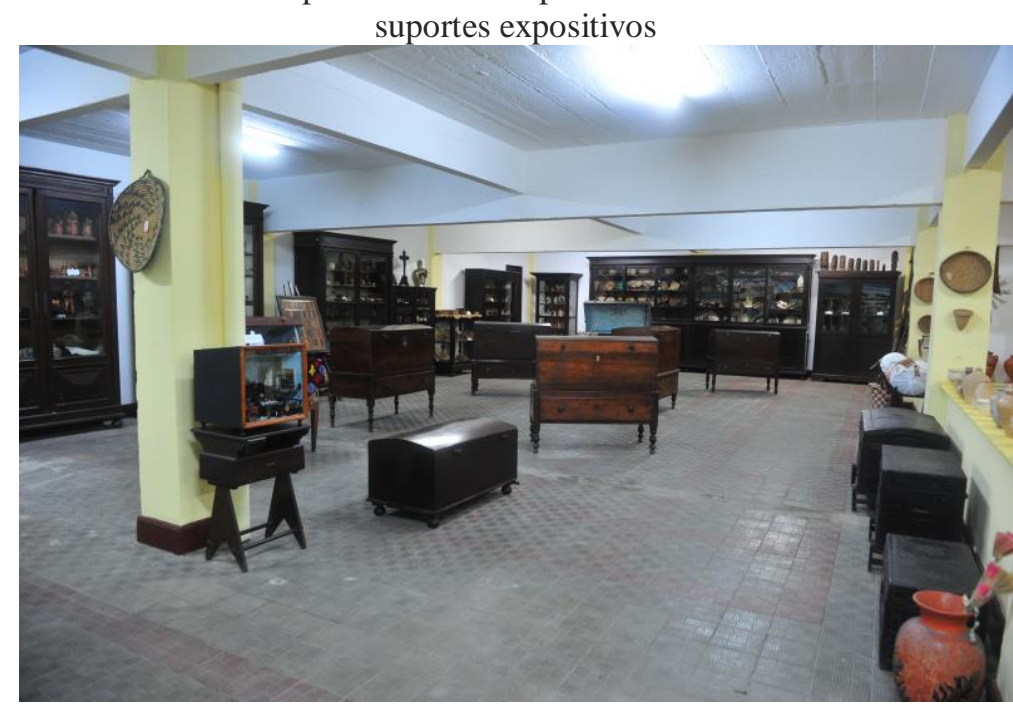

Foto: Cunha (2014). 
Figura 7 - Museu de Arte Popular IFB - vitrines de dupla face envidraçada

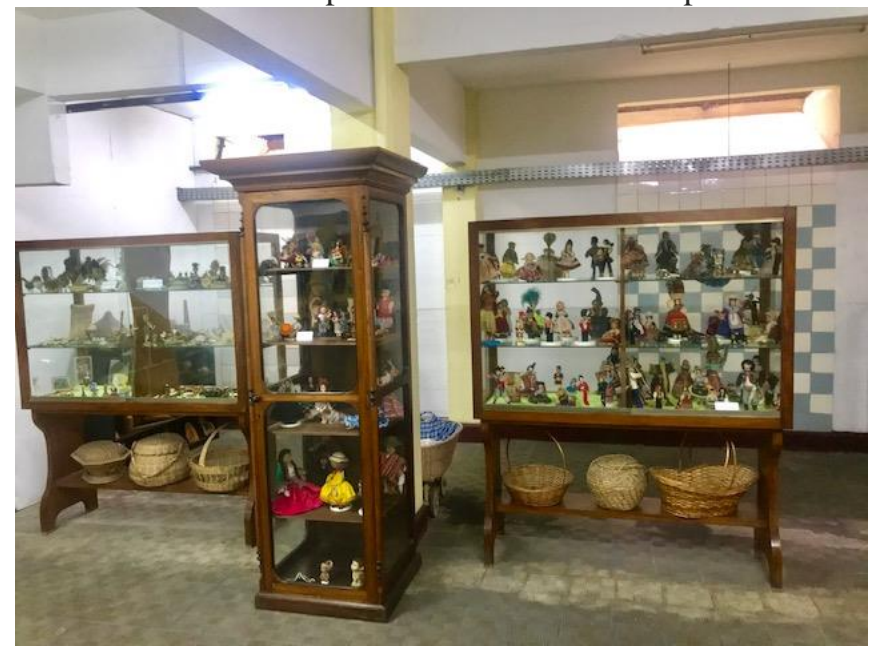

Foto: Castro (2018).

Figuras 8 e 9 - Suportes do segmento de cerâmica do $\mathrm{IFB}^{20}$, réplica dos suportes do Museu de Arte Popular - Portugal

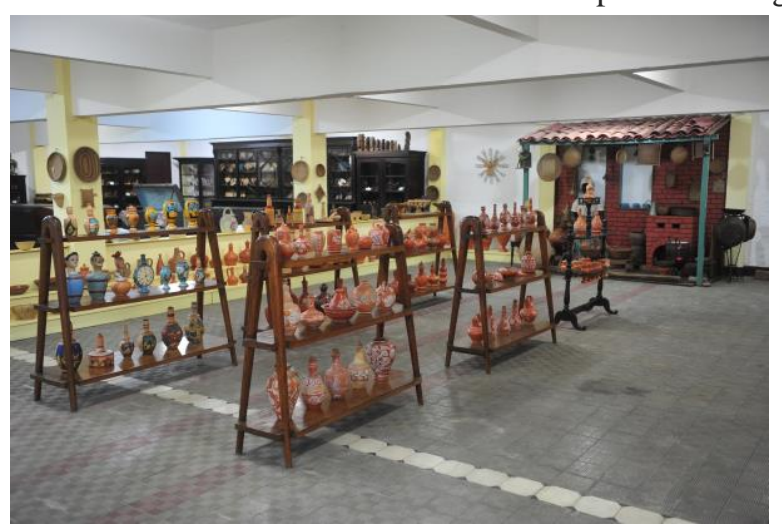

Fonte: arquivo pessoal (2014).

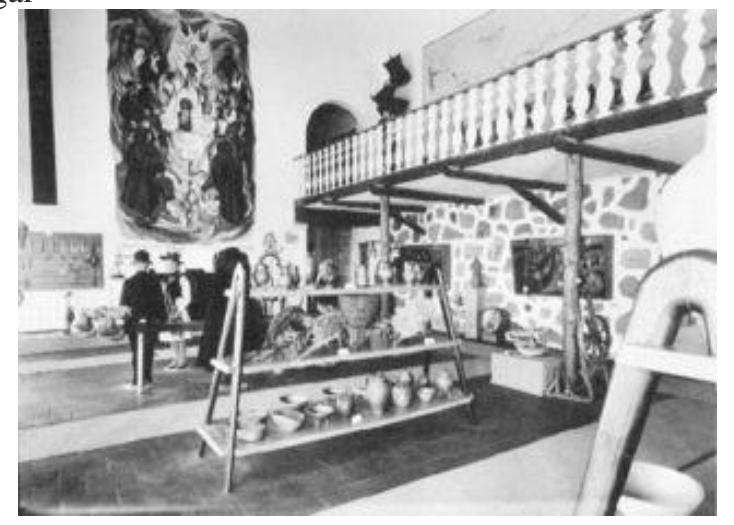

Fonte: Castelo Branco (1948) $)^{21}$.

Para a produção do mobiliário expositivo de alto custo e equipar o Museu no subsolo, cuja condição provisória era sinalizada em documentos, foi preciso contar com apoio externo assim registrado em documento posterior ${ }^{22}$, para que chegasse a ter autonomia e melhores instalações conforme texto de Marieta Alves ${ }^{23}$, expectativa declarada no opúsculo Museu de Arte Popular de 1957 preparado para o III Congresso Nacional de Folclore em 1957.

A ambientação da "cozinha de casa de família" (Figura 10) com a "nega" em pano e tamanho natural (Figura 11) tornou-se atração da exposição. Não é o caso aqui de analisar implicações e significados da representação de homens e mulheres negras em exposições museológicas ${ }^{24}$, todavia, a figura em pano, reiteradamente fotografada ou citada nos jornais ao se referirem ao Museu de 
Arte Popular, compõe o diorama representando o lugar para cozimento de alimentos em fogão a lenha e utensílios - pilões, tachos de ferro ou cobre, abanos, peneiras e outras cestarias ${ }^{25}$.

Figura 10 - Fragmento de noticia de jornal indicando a "cozinha de casa de família"

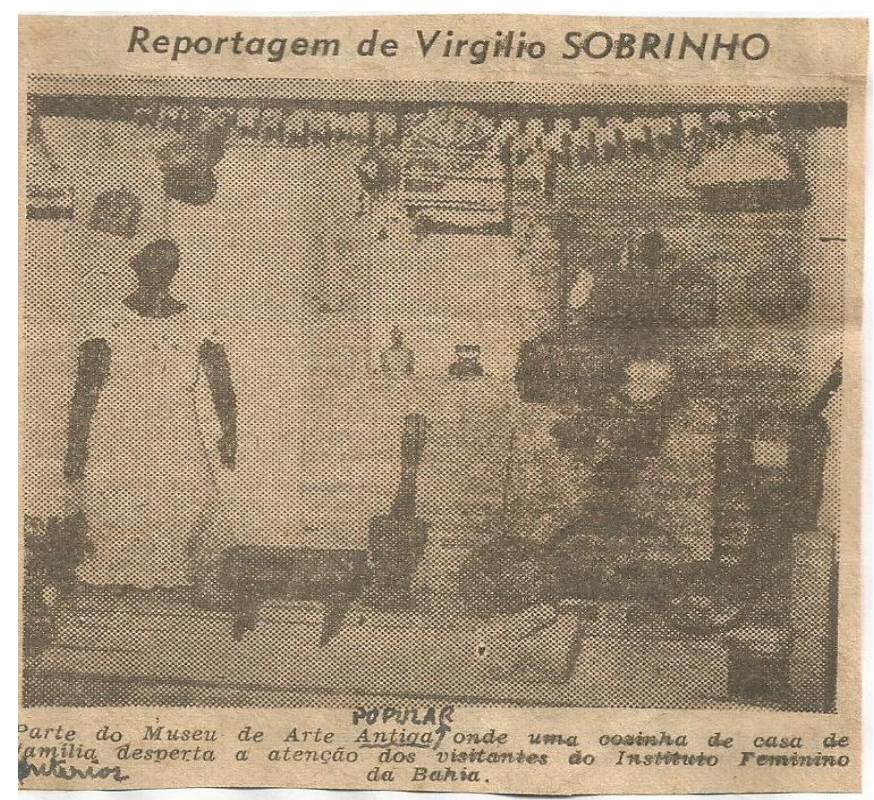

Fonte: Imagem digitalizada em CD disponibilizada pela Biblioteca do IFB.

Figura 11 - Contraponto entre a "nega" (grifo da notícia) em tamanho natural e o móvel de "muito valor" (grifo nosso)

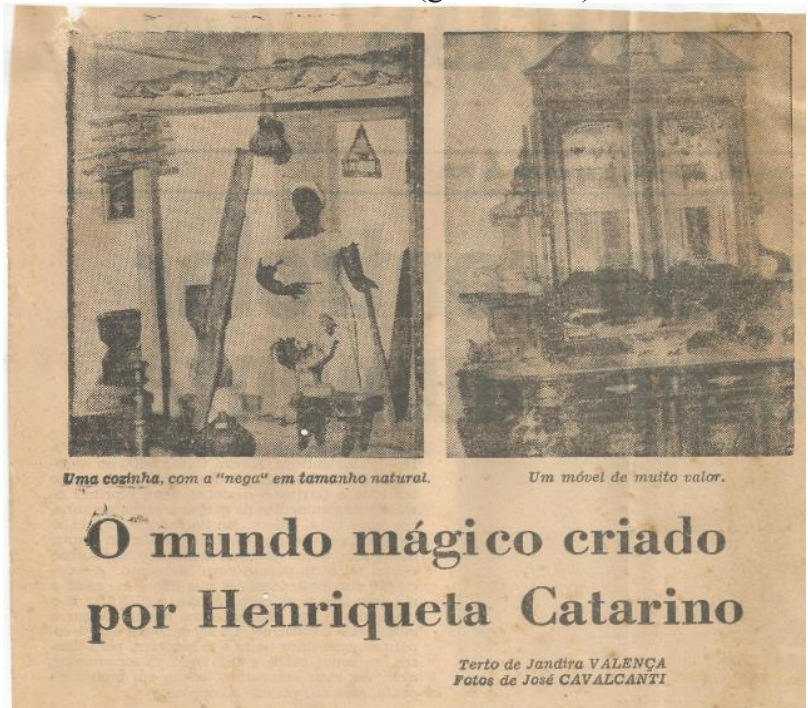

Fonte: Imagem digitalizada em CD disponibilizada pela Biblioteca do IFB.

O acervo do Museu de Arte Popular do IFB tornou-se requisitado e endereço certo para eventos como congressos, que estreitavam a rede de interesses e relações, ou semanas comemorativas do folclore. Henriqueta 
Catharino, reconhecida pelos serviços prestados à cultura, artes e "letras pátrias" da Bahia, integrou a Comissão Bahiana de Folclore $(1951)^{26}$. Em 1955, acontecia em Salvador o III Congresso Nacional de Turismo, e no IFB a "Grande mostra de arte popular"27, preparada em seções, teve "a Baiana" adornada com roupas, joias e panos da $\operatorname{Costa}^{28}$. Outro evento que requisitou a visita ao Museu foi o III Congresso Brasileiro de Folclore $(1957)^{29}$, oportunidade para a reunião de folcloristas que tiveram em Renato Almeida, via Itamaraty, a personalidade que lutou pela legitimação do Folclore (e folcloristas) na condição de área de estudos no Brasil, marginalizada nas Ciências Sociais, tema de debates nos anos 1940 e década seguinte (VILHENA, 1997) ${ }^{30}$. Renato Almeida foi autor de longo e elogiadíssimo texto sobre o Museu - e o trabalho de Henriqueta Catharino -, publicado anos antes (1954) no Diário da Bahia ${ }^{31}$, cuja ênfase no popular, equivalente ao tradicional, opera no discurso como contraponto às perdas ocasionadas pela modernização. Tem-se aí um provável ponto de contato entre o IFB e os folcloristas.

Com efeito, as 'baianas' e incluso os Orixás se transformaram em ícones da $\mathrm{Bahia}^{32}$, fortalecendo o tripé - tradição, cultura popular e autenticidade cultural - confluído nos enunciados sobre a preservação do patrimônio cultural baiano $^{33}$, ao tempo em que integrava representações artísticas atestando supostas características da cultura baiana ${ }^{34}$, bem como na literatura (como o fez Jorge Amado), ou em guias turísticos da Bahia dos anos $1950^{35}$, em paradoxal contraste que, de um lado, valorizava as manifestações da população negra e, por outro, as marginalizava (ROMO, 2018) ${ }^{36}$. Nesse aspecto, a representação folclórica de modo geral carregava a tradição para alicerçar a "estrutura da sociedade brasileira" e, desta maneira, formar a "mentalidade turística" despercebida no Brasil (TOURINHO, 1961, p. 69, grifo nosso) ${ }^{37}$.

Se para considerações sobre o espaço e a estrutura expográfica conta-se com certa trajetória cronológica relativamente definida (de 1923 a 1939) e, por isso mesmo, mais visível, sobre a formação da coleção de artefatos do popular e do próprio Museu, conta-se com indícios contraditórios, sendo necessário aprofundar as investigações para a solução de questões. Ainda assim, apresentamos, a seguir, algumas questões iniciais. 


\section{A Coleção de Arte Popular no IFB}

Sobre a formação da coleção têm-se indicações com anos de distanciamento em décadas distintas. Desde um vago "há muitos anos", em notícia informando que Henriqueta Catharino adquiria "material para um Museu de Arte Popular" 38 (ARQUIVO IFB, [19--]) a anos específicos: 1926 e 1929, em documento enviado à Bahiatursa (1974), com a significativa informação que o IFB recebera naquele ano peças do candomblé doadas por um delegado da polícia (Dr. Tancredo Teixeira), formando o "primeiro Museu de Arte Popular da Bahia"39 (ARQUIVO IFB, 1974); 1931 (por informação contida no site), e a notícia da inauguração do Museu anunciada em 1957, quando do III Congresso de Folclore na cidade do Salvador (Figura 12) ${ }^{40}$.

Figura 12 - Inauguração do Museu de Arte Popular

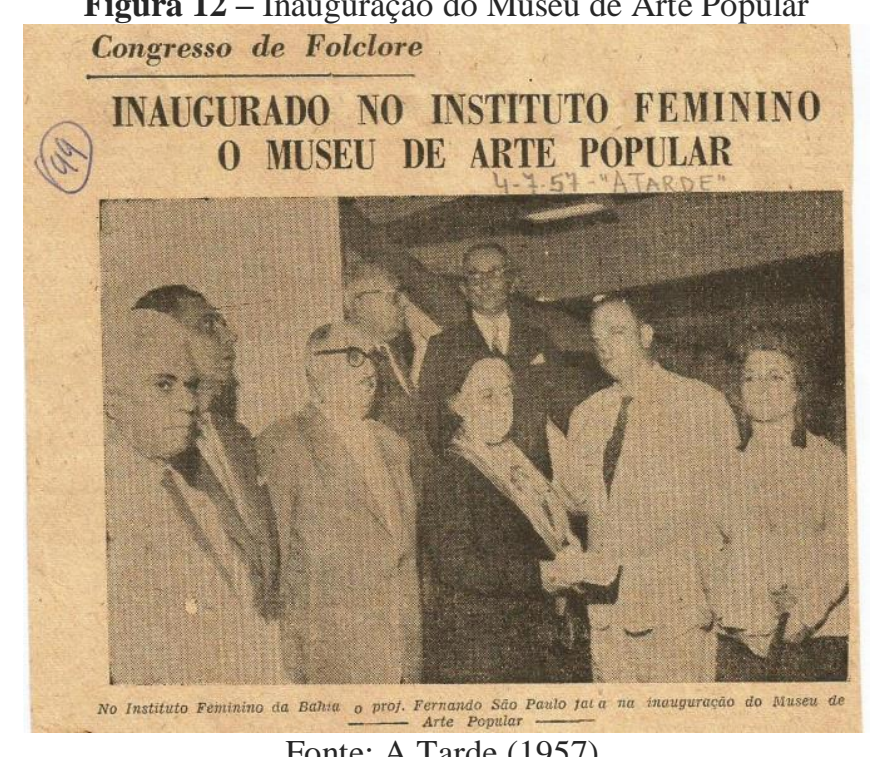

Fonte: A Tarde (1957)

Nota: "No Instituto Feminino da Bahia, o prof. Fernando São Paulo [sic] fala na inauguração do Museu de Arte Popular - A Tarde, 04 jul. 1957."

Em estudo recente concluímos que a constituição da coleção de artefatos populares se deu paulatinamente mesclando trabalhos manuais resultantes dos projetos assistencialistas, apresentados em mostras temporárias (para venda em bazares realizados pela Associação de Senhoras Brasileiras, no Rio de Janeiro $)^{41}$, com trabalhos de outras artesãs (ou artesãos) não vinculados diretamente aos projetos, porém representativos da artesania regional. Caso, por exemplo, de pequenas esculturas executadas por duas irmãs (Ana e Olegária de Almeida) da região de Jacuípe (litoral norte da cidade do Salvador), 
caracterizadas, por Marieta Alves, a primeira secretária de Henriqueta Catharino no $\mathrm{IFB}^{42}$, como "tipicamente populares" $"$. A conhecida benemerência de Henriqueta, sua obra e o círculo social do qual participava - e contava, para desenvolver os projetos - não descarta a probabilidade de que ela mesma comprasse trabalhos artesanais motivada pela ajuda caritativa ou dar incentivo além de possíveis presentes ou ainda pelo próprio gosto (CERÁVOLO, 2020).

O deslocamento paulatino dos artefatos do popular dos bazares para alcançar a autonomia do acervo e do Museu atesta-se, nitidamente, no referido texto de Marieta Alves (1957), não obstante parta do Museu de Arte Antiga, criado para conservar "o que fez ou possuiu a mulher bahiana no passado" (ALVES, 1957, não paginada). O texto transmite a intenção em marcar a formação do acervo do popular anterior ao movimento dos folcloristas, no entanto, é importante salientar a diferença expressiva que não diz respeito a uma data ou outra mas, sim, às intenções: para os folcloristas tratava-se de coleta em campo para pesquisas ${ }^{44}$. Marieta Alves interpreta como "evolução" um inicial "Museu Miscelânia" em que havia de tudo, incluso peças de arte popular, de valor para os fundadores do Instituto. O relato pautado em notícias de jornais, procura enfatizar a legitimidade do cunho regional dos ancestrais baianos e o pitoresco e original (grifos da autora) que, ao migrar para a condição de documento historiográfico do IFB, agrupa dados valiosos sobre o gerar da coleção, os locais e as titulações atribuídas ao Museu trazendo indicações sobre o acervo e equipamentos expográficos.

Sobre o gerar da coleção tem-se a doação, pelas mãos do Monsenhor Flaviano Osório Pimentel, com quem Henriqueta Catarino iniciou os trabalhos assistencialistas, de:

[...] quadros, trabalhos mimosos de conchas e pedras preciosas, adornos e objetos de fantasia, espécimes da fauna, apresentação multiforme da flora, a célebre rêde que servira ao vigoroso escritor Euclides da Cunha, e muitos mostruários praticamente elaborados, no conjunto e disposições elogiáveis [...] (O IMPARCIAL, 1938, não paginada)

Ao Monsenhor Flaviano é atribuída a criação do Museu Regional (no prédio do Rosário, no. 215$)^{45}$, mas, no mesmo documento tem-se, ao passar do 
tempo, Museu Popular e Museu de Arte Popular. Quanto aos locais anteriores ao prédio de 1939, diz da inadequação além de agrupar, que se entende por acumular, das peças em vitrines. Sobre o acervo, no mesmo ano da mudança para a sede de 1939, o informe de mais uma exposição de prendas femininas para a "grande exposição das Senhoras Brasileiras" (grifo nosso) e o retorno dos trabalhos das irmãs Ana e Olegária de Almeida (bonecas, caixinhas e animais), observando-se que não se sabe se ocorreu na sede nova ou em endereço anterior. O problema do arranjo provisório das peças de arte popular no subsolo encontrou apoio e auxilio no Ministro da Educação Simões Filho ${ }^{46}$, quando do III Congresso de Folclore; antes o IFB não pudera resolver por dificuldades materiais $^{47}$.

$\mathrm{Na}$ sede de 1939, a exposição do popular no IFB se instalou definitivamente no subsolo. Todavia, o noticiário nem sempre ajuda a entender se as exposições temporárias ocorriam também no espaço do Museu (lembrando a sala criada em 1940 por Henriqueta no primeiro andar, mobiliada para a exposição de têxteis e até os dias de hoje destinada às mostras temporárias). Ao festejar os 50 anos de atividades ocorreram em paralelo "exposições de arte no museu da Fundação" apresentando o manto e saia da Princesa Isabel ${ }^{48}$, e a popular de "cunho inédito" produzida e executada pela artista Waldete Cristina, com cenários pintados e as ordens religiosas em pano ${ }^{49}$, em esclarecedora noticia sobre a angulação religiosa católica do popular no IFB.

O quantitativo de artefatos da coleção do popular é desconhecido ${ }^{50}$. A folclorista Hildegardes Vianna fala em mais de 2 mil peças ${ }^{51}$. Segundo o documento da Bahiatursa (1974), anteriormente citado, o museu

[...] praticamente abrange todas as manifestações dos artistas obscuros que fixaram vezes genialmente, os ritos africanos, as danças, a cerâmica, redes e instrumentos, bonecas, trabalhos com os mais variados materiais como: conhas, cavacos, sementes, piaçava, pele de ovo, pão, penas, pano, lata, etc. Possui também 2 peças originais: um tear onde se fabricam panos da costa e um torno de oleiro e mais carranca de São Francisco, Jangada, etc. A cerâmica popular de várias regiões brasileiras, notadamente a baiana, são ponto alto, além dos trançados, tecelagem, esculturas, objetos de couro, chifes, etc. (BAHIATURSA, 1974, não paginada) 
O documento menciona a cozinha com "preta velha com típica indumentária"; "farto material de candomblé", artesanato indígena; artefatos de pesca" e, em separado, a coleção de ciências naturais para auxiliar as aulas práticas $^{52}$.

No que diz respeito ao tear, peça doada em 1955 por Abdias do Nascimento Nobre (Figura 13), destaca-se uma situação singular. Mestre Abdias (Salvador, 1910-1990), considerado o último representante da linhagem de artesãos produtores do pano da costa ou alaká, dedicado ao ensino da sua arte, instrutor em cursos de formação (impedindo o desaparecimento do ofício), mesmo após a doação continuou a usar o tear em exposição no Museu ${ }^{53}$, o que de certa forma comprova a dinâmica deste acervo (ou outros), em evidente demonstrativo das forças mobilizadoras que operam em museus.

Figura 13 - O tear do Mestre Abdias na exposição do Museu de Arte Popular/IFB

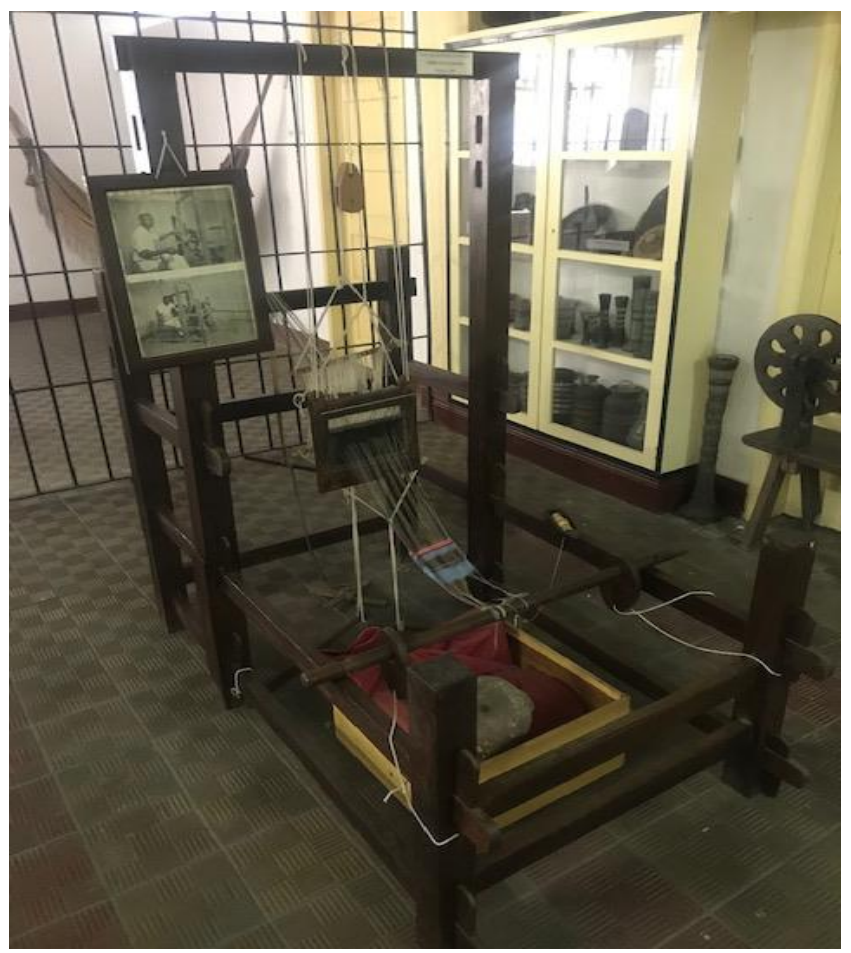

Fonte: Castro (2018).

Fato é que de acordo com Marijara Queiróz, até 2011 a coleção de arte popular não estava inventariada (QUEIRÓZ, 2016), embora elemento fundamental de registro museológico e para pesquisas internas ou externas. Pautados pelo que se vê na exposição do acervo do popular do IFB - e as figuras 
(5, 6 e 7) o demonstram - trata-se de coleção volumosa em quantidade, rica em peças de artesãos que se tornaram conhecidos ou não, mas, nem por isso de menor expressão, e eclética nos materiais e diferentes temporalidades o que reforça, a nosso ver, a importância para o patrimônio cultural da Bahia no mais amplo sentido. Dito de outro modo, sob essas características o que se tem são camadas de historiografia que ultrapassam a do próprio IFB, ainda a serem pesquisadas.

\section{Conclusão inconclusa...}

Do que foi possível averiguar nas fontes consultadas, referenciadas ao longo do texto, a expansão dos projetos de Henriqueta Catharino resultou na construção de edificação própria para abrigar a sede do Instituto Feminino da Bahia, cujo subsolo abrigou a coleção de artefatos do popular amealhada ao longo dos anos e que ali se mantém até os dias atuais. Ao que tudo indica, não houve mudanças radicais nos equipamentos expositivos quer os projetados quer os adaptados. A coleção propriamente dita se caracteriza pela diversidade eclética de materiais, formas e expressões do popular nacional ou do exterior. Pouco comentamos sobre o arranjo dos artefatos que entendemos linear e a-histórico, ou seja, atemporal (relativo portanto à dimensão da ucronia a que nos referimos anteriormente), sequenciado em temas formando núcleos (cenas do cotidiano e esculturas em argila; bonecas de pano; cerâmica de uso doméstico; cestaria citando exemplos), justamente pela impossibilidade de re-visitar, neste momento, a exposição.

A finalização abrupta das considerações relativas à Coleção de arte popular, melhor dizendo, da cultura popular no IFB, com informação relativa ao diorama ainda existente no Museu, não é fruto da limitação de espaço para a escrita, contingenciada pelas normas necessárias relativas à publicação; certamente, um limite que sempre circunscreve os resultados da edição textual. Mas, no caso específico deste ensaio, a questão necessária para remarcar é o fato de que ainda há muito a ser prospectado, analisado, registrado sobre esse museu, sua história, acervos, práticas e importância. 
Como museólogos e pesquisadores com formação em história, acreditamos que tal incompletude - de dados, evidências, documentos e assertivas - acaba sendo um caráter, na maioria das vezes, inerente a todos os fenômenos e fatos que investigamos. Assim, a situação não deve ser tomada como desestímulo ou barreira para que não sigamos em frente no objetivo de desvendar memórias e narrativas institucionais. Pelo contrário, favorece constituir-se como desafio a ser enfrentado com o fim de ampliar o entendimento sobre aquilo que estamos investigando provocados por nossas inquietações epistêmicas e, igualmente, pelo reconhecimento da necessidade de trazer a público fatos e questões que repousam no esquecimento, apesar da sua importância.

Ainda que marcado pela certeza de que muito ainda há a refletir, a partir do que já conseguimos apreender e, principalmente, pelas lacunas, a intenção é a de que o escrito seja canal para o estabelecimento de diálogos com outros pesquisadores e com a própria instituição visando ampliar os resultados de projetos similares, voltados para a construção do panorama sobre a história de instituições museológicas no Brasil.

Por fim, ressaltamos que as reflexões aqui registradas são fruto de pesquisa realizada ao longo de anos, com interrupções que são comuns em processos de investigação, e só foram possíveis pelo acolhimento institucional, por recursos que permitiram a participação de bolsistas de iniciação científica e pelas redes e diálogos com outros investigadores.

\section{Referências}

ALVES, Marieta. Museu de arte popular do Instituto Feminino da Bahia. Salvador, IFB, 1957.

ALVES, Marieta. Henriqueta Martins Catharino - sua vida e sua obra. Museu do Traje e do Têxtil. Salvador : Fundação Instituto Feminino da Bahia, 2003.

A Tarde. Inauguração do Museu de Arte Popular. 04 jul. 1957.

BAHIATURSA. Doação de expositores. Salvador: IFB, 1974. 
BATISTA, Marta Rossetti (org.). COLEÇÃO MÁRIO DE ANDRADE. Religião e Magia/Música e Dança/Cotidiano. São Paulo: EDUSP : Impressa Oficial do Estado de São Paulo, 2004.

CASTELO BRANCO, Antônio. Suportes do segmento de cerâmica do IFB, réplica dos suportes do Museu de Arte Popular - Portugal. 1948. 1 fotografia.

CASTRO, Silvana M. M. B. de A . Museu de Arte Popular IFB - vitrines de dupla face envidraçada. 2018. 1 fotografia.

CASTRO, Silvana M. M. B. de A. Equipamento expositivo: estantes paralelas à parede - Museu de Arte Popular IFB. 2020. 1 fotografia.

CERÁVOLO, Suely Moraes. Pistas biográficas de Henriqueta Catharino e a Coleção de Arte Popular do Instituto Feminino da Bahia. Revista Brasileira de Pesquisa (Auto)biográfica, Salvador, v. 5, n. 14, p. 692-708, 2020.

COELHO NETTO, J. Teixeira. A construção do sentido na arquitetura. São Paulo: Perspectiva, 1999.

CUNHA, Marcelo Nascimento Bernardo da. Teatro de memórias, palco de esquecimentos: culturas africanas e das diásporas negras em exposições. (Tese) - Pontifícia Universidade Católica de São Paulo, São Paulo, 2006.

CUNHA, Marcelo Nascimento Bernardo da. A Exposição Museológica Como Estratégia Comunicacional: o tratamento museológico da herança patrimonial. Revista Magistro, Rio de Janeiro, v. 01, n. 01, p. 109-120, 2010.

CUNHA, Marcelo Nascimento Bernardo da. Museu de Arte Popular IFB exemplos de móveis domésticos utilizados como suportes expositivos. 2014. 1 fotografia.

CUNHA, Marcelo Nascimento Bernardo da Cunha. Corpos, Discursos e Exposições: A Coleção do Museu Antropológico e Etnográfico Estácio de Lima (Bahia,Brasil). In: MAGALHÃES, Fernando et al. (Coord.). Museologia e Patrimônio. Leiria: Escola Superior de Educação e Ciências Sociais / Politécnico de Leiria, 2019.

DELOCHE, Bernard. Mythologie du musée: de l'uchronie à l'utopie. França: Le Cavallier Blue Editions, 2010.

DESVALLÉES, André; MAIRESSE, Françoise (ed.). Conceitos-chave de Museologia. São Paulo: Comitê Brasileiro do Conselho Internacional de Museus: Pinacoteca do Estado de São Paulo: Secretaria de Estado da Cultura, 2013. 
DOHMANN, Marcus. A experiência material: a cultura do objeto. In:

DOHMANN, Marcus (org.). A experiência material: a cultura do objeto. Rio de Janeiro: Rio Books, 2013.

FREIRE, Luiz Alberto Ribeiro; HERNANDEZ, Maria Hermínia Oliveira (orgs.). Dicionário Manuel Querino de arte na Bahia. Salvador: EBA-UFBA: CAHL-UFRB: 2014.

LEAL, Claudia Feirabend Baeta (org.). As missões da UNESCO no Brasil: Michel Parent. Rio de Janeiro: IPHAN, 2008.

LEITE, Rinaldo Cesar Nascimento. A Rainha Destronada. Discursos das elites sobre as grandezas e infortúnios da Bahia nas primeiras décadas republicanas. Feira de Santana: UEFS, 2012.

MUSEU DO TRAJE E DO TÊXTIL. FUNDAÇÃO INSTITUTO FEMININO DA BAHIA. [apresentação Dom. Geraldo Majella Cardeal Agnelo: texto por Ana Lucia Uchoa Peixoto, Marieta Alves, Maria Júlia Alves de Souza: fotografias, Sergio Benutti. Salvador: Fundação Instituto Feminino da Bahia, 2003.

O Imparcial. Edição Especial, 1934. Álbum Recordando, IFB. 1 fotografia. PASSOS, Elizete Silva. Henriqueta Catharino. Salvador : EDUFBA/FACED, 2010.

PASSOS, Elizete Silva. Mulheres moralmente fortes. Salvador : Gráfica Santa Helena, 1993.

PEIXOTO, Ana Lúcia Uchoa. O Museu do Traje e do Têxtil. In: Museu do Traje e do Têxtil. Salvador : Fundação Instituto Feminino da Bahia, 2003.

QUEIRÓZ, Marijara Sousa. De escola para mulheres a museu feminino: o colecionismo de Henriqueta Martins Catharino. In: Seminário Nacional de História da Ciência e da Tecnologia, 15., 2016, Florianópolis. Anais [...]. Florianópolis: UFSC, 2016.

ROMO, Anadelia A. Writing Bahian Identity: Crafting New Narratives of Blackness in Salvador, Brazil 1940-1950. Journal Latin American Studies, Cambridge, v. 50, p. 805-832, 2018.

SANTOS, Jancileide Souza de. Coleções, Colecionismo e Colecionadores: um estudo sobre o processo de legitimidade artística da produção de arte popular católica na Bahia entre as décadas de 1940 a 1960. (Dissertação) - Programa de Pós-graduação Artes Visuais, Escola de Belas Artes, Universidade Federal da Bahia, 2013. 
SOARES, Lélia Gontijo. Mário de Andrade e o Folclore. In: Mário de Andrade e a Sociedade de Etnografia e Folclore. Departamento de Cultura da Prefeitura do Município de São Paulo1936-1939. Rio de Janeiro : FUNARTE, Instituto Nacional de Folclore; São Paulo : Secretaria Municipal de Cultura, 1983.

SOUZA, Jean Costa. O Culto à Tradição de nossa gente: a fabricação do Folclore Sergipano em exposições museológicas (1948-1976). (Dissertação) Programa de Pós-graduação Interdisciplinar em Culturas Populares, Fundação Universidade Federal de Sergipe, Aracajú, 2019.

SOUZA, Mariella Araújo de. O concreto armado nas edificações de Salvador no período entre guerras (1919-1938). (Tese) - Programa de Pós-graduação Arquitetura e Urbanismo, Faculdade de Arquitetura Universidade Federal da Bahia, Salvador, 2017.

SOUZA, Mariella Araújo de. Planta baixa do Pavimento Térreo que corresponde ao subsolo da edificação do IFB; área colorida corresponde ao Museu de Arte Popular. 2020. 1 fotografia.

TOURINHO, Antonio C. Estudo sobre o Turismo. Salvador : Imprensa Oficial da Bahia, 1961.

VILHENA, Luís Rodolfo. Projeto e missão. O movimento folclórico brasileiro 1974-1964. Rio de Janeiro: Funaerte: Fundação Getúlio Vargas, 1997.

\title{
Reflexions on the Museu de Arte Popular do Instituto Feminino da Bahia-IFB
}

\begin{abstract}
In this article the reflexions on the Museu de Arte Popular do Instituto Feminino da Bahia-IFB (Museum of Popular Art of the Women's Institute of Bahia State), a school for women that marked an era in the city of Salvador from the first decades to the mid-twentieh century, aim to highligth aspects still unexplored on the relationship between the building and the expographic structure with the Popular Art Collection of this Bahian institution. Based on a corpus of documents an attempt is made to correlate the sources consulted, in order to recover the trajectory that led to the assemblage of the collection, and to describe the characteristics of the place that has been sheltering it since 1939 as well as equipments and ways of exhibition, concluding on the importance and need for more research to reveal the layers of historiography that go beyond the history of the Instituto Feminino itself.
\end{abstract}

Keywords: Museum of Popular Art of Instituto Feminino da Bahia. Collection. Exhibition space. 
Recebido: 31/07/2020

Aceito: 11/09/2020

\section{Declaração de autoria}

Concepção e elaboração do estudo: Marcelo Nascimento Bernardo da Cunha, Suely Moraes Cerávolo

Coleta de dados: Marcelo Nascimento Bernardo da Cunha, Suely Moraes Cerávolo

Análise e discussão de dados: Marcelo Nascimento Bernardo da Cunha, Suely Moraes Cerávolo

Redação e revisão do manuscrito: Marcel o Nascimento Bernardo da Cunha, Suely Moraes Cerávolo

\section{Como citar}

CUNHA, Marcelo Nascimento Bernardo da; CERÁVOLO, Suely Moraes.

Reflexões sobre o Museu de Arte Popular do Instituto Feminino da Bahia. Em Questão, Porto Alegre, v. 26, p. 206-234, Edição Especial Dossiê Patrimônio e Culturas Tradicionais, 2020. DOI: http://dx.doi.org/10.19132/1808-

5245260.206-234

${ }^{1}$ Nascida em Feira de Santana - Bahia (1886-1969), filha do português Bernardo Catharino rico industrial de têxteis casado com Úrsula Martins Catharino.

${ }^{2}$ Quer o Museu do Estado da Bahia criado em 1918, quer o do Instituto Geográfico e Histórico da Bahia (criado pelo Estatuto de 1894) contavam, nesse momento, com acervo classificado como popular e etnográfico.

${ }^{3}$ Cofundador do Instituto e apoiador das ações de Henriqueta Catharino.

4 A Casa São Vicente abrigava: biblioteca, agência de trabalhos manuais e de empregos, restaurante, pensão para mulheres; a Escola Comercial Feminina, cursos de curta duração de fins profissionais (datilografia, estenografia, harmonium, francês e inglês). Em 1923 foi criado o Ateliê São José para confecções de lingeries e vestidos finos, no endereço da Av. Sete de Setembro (PASSOS, 2010).

${ }^{5}$ Localizados no perímetro central da cidade, considerado área nobre, à época.

${ }^{6}$ Lei 2.176 - junho 1929. Segundo um blog dedicado ao Instituto (https://fifb.blogspot.com/) em 1950 foi reconhecido pelo Governo do Estado da Bahia. Também decretado de Utilidade Pública pelo Governo Federal em 22/02/1963, confirmado em decreto de 28/05/1992.

${ }^{7}$ Onde se promove a emancipação da mulher pelo trabalho e pelas acções meritorias. Uma grande obra social que honra a cultura bahiana e exalta os sentimentos religiosos da população catholica. O Instituto Feminino da Bahia e sua elevada finalidade. O Imparcial, 21.06.1934.

${ }^{8}$ Álbum Recordando composto por recortes de jornais, iniciado com reportagens da década de 1920 do Arquivo do IFB.

${ }^{9}$ A Tarde, 03.03.1939. (Recorte de jornal digitalizado; imagem cedida pela Biblioteca do IFB). Em apoio à pesquisa relacionada a notícias de jornal sobre o IFB, a bibliotecária do Instituto disponibilizou dois CD's contendo recortes de jornais digitalizados. Não há neste material 
digital nenhuma cota de classificação e localização, além dos elementos contidos em cada imagem, motivo pelo qual estas fontes serão referenciadas sem detalhamentos de classificação.

${ }^{10}$ Ver em Mariella Souza (2017): figura 70, p.131 (posteriormente piso destinado ao Museu Henriqueta Catharino; e a figura 71, p.132 ( $3^{\circ}$. Andar) piso ocupado pela Pensão, depois Museu do Traje e do Têxtil.

${ }^{11}$ Projetado e construído pela Companhia Construtora Nacional (SOUZA, 2017, p.128).

${ }^{12}$ Como em Museu de Arte Feminina, reportagem de Olga Orby para A Gazeta, 26.02,1947

1325 Anos de Serviços à Mulher Bahiana. O Instituto Feminino está comemorando hoje, as suas Bodas de Prata. A Tarde, 05.10.1948. A imagem da entrada principal do IFB é usada ainda hoje imagem utilizada em reportagens ou blogs como https://institutofeminino.org.br/.

${ }^{14}$ Há uma variante na definição dos pisos do edifício: em alguns documentos e citações o primeiro piso é classificado como subsolo, enquanto em outros aparece como térreo, como é o caso da planta aqui apresentada.

${ }^{15}$ A área para o Museu ficou ladeada à direita por: serviços de hidroterapia (com gabinete biométrico, sala de espera, de repouso, a de banhos carbogasosos, duchas diversas, banhos à vapor, duchas escocesas, duchas circulares) despensa; depósito. À esquerda (ao fundo): salão de jogos; elevador, sala de serviço, almoxarifado e depósito, casa forte. Os serviços de hidroterapia eram divulgados em jornais oferecendo "duchas, banos carbo gasosos, banhos turcos e de sede" e massagens (A Tarde, 2.10.1947; grifo da notícia).

${ }^{16}$ A planta baixa de 1956, adaptada cf. Mariella Souza, traz a escada 1:100, mas não as cotas. Em exercício de aproximação tomando por referência as possíveis dimensões de uma escada (esquerda, ao fundo) e computando: área coberta, corredores laterais à piscina, a piscina e as duas salas entre o almoxarifado e a dispensa e depósito (à direita), Cynthia C. Calia (arquiteta, em 09.05.2020) chegou ao cálculo de $321,9^{\mathrm{m} 2}$ para a área ocupada pela exposição do Museu de Arte Popular.

${ }^{17}$ Outros pavimentos podem ser consultados nas figuras: 68 (p.129); 69 (p.130); 70 (p.131); 71 (p.132), (SOUZA, 2017)

${ }^{18}$ O IFB participava de competições esportivas e realizava certames de vôlei e natação entre equipes da escola.

${ }_{19}$ Móveis verticais em madeira com partes envidraçadas para mostrar objetos.

${ }^{20}$ A imagem do mesmo segmento de cerâmica do IFB, em outro ângulo, estampou a nota Museu de Arte Popular do Instituto Feminino da Bahia (A Tarde, 25.04.1959) do intelectual baiano José Antonio do Prado Valladares na série Conhece Tua Cidade.

${ }^{21}$ Suporte expositivo do Museu de Arte Popular: imagens e palavras. Sala de Trás os Montes, Foto António Castelo Branco, 1948. Disponível em: https://alexandrepomar.typepad.com/alexandre_pomar/actual/page/7/. Acesso 09/05/2020

${ }^{22}$ Em documento à Bahiatursa (1974) lê-se a informação sobre a doação de expositores e os pertencentes à "própria Presidente" (D. Henriqueta) para o chamado Museu de Arte Antiga. ("Fundação do Instituto Feminino da Bahia" - papel timbrado da Bahiatursa, 1974, assinado por Lúcia Marques, com a notação 033.11 (814.21) Fund. Inst. Femin. da Bahia BHA - e carimbo da Biblioteca Margarida Costa Pinto, no. 2867 (Arquivo do IFB).

${ }_{23}$ Museu de Arte Popular do Instituto Feminino da Bahia texto para enviar ao $1^{\circ}$. Congresso Nacional de Museus em Ouro Preto (julho de 1956). Datilografado com nota explicativa no final "Trabalho escrito por D. Marieta Alves, historiadora e 1a secretária do IFB. Data: 18/09/1959." Arquivo do IFB.

${ }^{24}$ Sobre a imagem da mulher negra no IFB consultar SILVA, Joana Angélica Flores. A representação das mulheres negras nos Museus de Salvador: uma análise em Branco e Preto. Dissertação. $\quad$ PPGMuseu/FFCH/UFBA, $2015 . \quad$ Disponível https://repositorio.ufba.br/ri/handle/ri/18548. Acesso 09.05.2020. Sobre representação de culturas africanas e afro-brasileira em exposições museológicas consultar CUNHA, Marcelo Nascimento Bernardo da. Teatro de Memórias, Palcos de Esquecimentos: Culturas africanas e das diásporas negras em exposições. (Tese) - Programa de História Social/PUCSP, 2006.

Disponível em 
http://www.museologia.ffch.ufba.br/sites/museologia.ffch.ufba.br/files/tese_marcelo_nascime nto_bernardo_da_cunha.pdf. Acesso em 05/07/2020.

${ }^{25} \mathrm{O}$ diorama pode ser visto no site institucional (https://institutofeminino.org.br/arte-popular/) em que a boneca de pano aparece com saia de chita e bijuterias no lugar de joias.

${ }^{26}$ Uma visita ao Instituto Feminino da Comissão de Folcklore. A Tarde, 10.03.1951 (álbum Recordando, Arquivo do IFB).

${ }^{27}$ Grande mostra de arte popular. No Instituto Feminino uma das grandes atrações do Congresso de Turismo (álbum Recordando, Arquivo do IFB, p.270). Na oportunidade ocorreram visitas à monumentos na cidade; demonstrações do Maculelê; apresentação de teses pelas diversas comissões; filmes e a Exposição de Arte e Técnicas Populares com as peças baianas do IFB (A grande atração do Congresso: a Exposição de Arte e Técnica Populares no I. Feminino, Estado da Bahia, 1.11.1955) álbum Recordando, Arquivo do IFB).

${ }^{28}$ Outras seções: Cerâmica popular; Trançados (redes de pesca, cestarias, panos diversos, tear); Trabalhos com rendas de almofada, bonecas de pano e outras artesanias; Artigos de côco e chifre; Trabalhos em folhas de flandres Grande mostra de arte popular. No Instituto Feminino uma das grandes atrações do Congresso de Turismo. Diário da Bahia, 26.10,1955 (Imagem digitalizada em CD disponibilizado pela Biblioteca do IFB).

${ }^{29}$ A Gazeta (15.07.1957, SP) ao noticiar o III Congresso de Folclore realizado em Salvador com o prof. José Calazans secretário geral da Comissão baiana, auspícios da Comissão Nacional de Folclore - I.B.E.C.C e outras entidades, governo do Estado da Bahia e Prefeitura) indica a participação das seguintes comissões estaduais: Rio Grande do Sul, Santa Catarina, Paraná, São Paulo, Goiás, Alagoas, Sergipe, Pernambuco, Rio Grande do Norte, Maranhão, Pará, Rio de Janeiro e Distrito Federal. Dentre as personalidades cita-se: Gustavo Barroso, Théo Brandão, Felte Bezerra, Aurélio Buarque de Holanda. Uma das fotos do evento apresenta como pano de fundo o diomara do IFB (álbum Recordando, Arquivo do IFB). Outras mostras aconteceram no mesmo congresso: no saguão do Instituto Geográfico e Histórico da Bahia (escritos sobre tradições, costumes, lendas, e artes populares da região); no Belvedere da Sé pelos pesquisadores Carlos Galvão Krebs e Isolda Brans (artesanato do Rio Grande do Sul, com foco na tecelagem) e no Museu do Estado (Diario de Notícias, 21.7.1957; álbum Recordando, Arquivo IFB)

${ }^{30}$ A Comissão Nacional do Folclore (CNFL, 1947) foi comitê temático do Instituto Brasileiro de Educação, Ciência e Cultura (IBECC), organizada no Ministério das Relações Exteriores para representar o Brasil na UNESCO (VILHENA, 1997, p. 21). Dividia-se em setores: Documentação (Arquivo, Biblioteca, Museu, do Folclore, Mapoteca, Pinacoteca, Filmoteca e Discoteca do Folclore); Aplicação (Música, Artes Plásticas, Literatura, Educação); órgão de Relação (Intercâmbio Internacional e Nacional; Propaganda da CNFL, congressos gerais e especializados internacionais, interestaduais e regionais (SOUZA, 2019, p.74).

${ }^{31}$ Um Reduto de Baianidade. Casa de educação, relicário folclorico, uma instituição que honra e enaltece a Bahia, Diário da Bahia, 16.3.1954. (álbum Recordando, Arquivo do IFB)

${ }^{32}$ Uma fotografia do estande regional da Bahia com Renato Almeida em primeiro plano e a representação de Orixás pode ser vistos no encarte "Os Congressos: folcloristas, autoridades e o "popular” In VILHENA, 1997, s/n.

${ }^{33} \mathrm{O}$ patrimônio regional como fator para impulsionar o desenvolvimento do Estado recebeu estímulo nos anos 1960, com Missão Michel Parent financiada pela UNESCO, solicitada à então Diretoria do Patrimônio Histórico e Artístico Nacional (Dphan). Parent reforçando a importância do turismo, adicionou ao patrimônio edificado e natural as pouco fomentadas tradições e manifestações culturais (LEAL, 2008, p.13).

34 VER por ex.: MACIEL, Neila Dourado Gonçalves. Carybé e a Legitimação de um Discurso da Baianidade na Integração das Artes em Salvador. (Tese) - Programa de Pósgraduação Arquitetura e Urbanismo, Universidade Federal da Bahia, 2015. Disponível https://ppgau.ufba.br/sites/ppgau.ufba.br/files/tese_neilamaciel.pdf. Acesso 09.05.2020

35 A exemplo de: VALLADARES, José. Beabá da Bahia. Guia Turístico. Salvador: EDUFBA, 2012. 
${ }^{36}$ Importa lembrar que esse mesmo período marcado pela valorização de elementos afro, na perspectiva das artes e da cultura coincide, em todo o Brasil, com amplo processo de controle e perseguição das práticas associadas ao universo afro-brasileiro, na primeira metade do século XX e décadas seguintes, como foi o caso do candomblé e da capoeira, controlados e perseguidos pelas Delegacias de Jogos e Costumes. Vários objetos litúrgicos apreendidos nessas ações de controle foram destinados a coleções museológicas. Sobre a questão consultar CUNHA, Marcelo Nascimento Bernardo da Cunha. Corpos, Discursos e Exposições: A Coleção do Museu Antropológico e Etnográfico Estácio de Lima (Bahia, Brasil). In: MAGAlHÃES, Fernando et al. (Coord.). Museologia e Patrimônio. Leiria: Escola Superior de Educação e Ciências Sociais / Politécnico de Leiria, 2019.

${ }^{37}$ O Estado e a Prefeitura da cidade do Salvador junto ao SENAC Nacional propuseram o primeiro curso nacional para técnicos em turismo em regime intensivo (1960), do qual o Patrimônio Folclórico Brasileiro compunha uma das disciplinas, finalizado com a "excursão aula" em cidades do Recôncavo baiano ( $C$. de Turismo Excursionou ao Recôncavo, Jornal da Bahia, 27.09.1960).

${ }^{38}$ Grande mostra de arte popular. No Instituto Feminino um das grandes atrações do Congresso de Turismo (álbum Recordando, Arquivo do IFB, p. 270).

39 "Fundação do Instituto Feminino da Bahia" - papel timbrado da Bahiatursa, 1974, assinado por Lúcia Marques, com a notação 033.11 (814.21) Fund. Inst. Femin. da Bahia BHA - e carimbo da Biblioteca Margarida Costa Pinto, no. 2867 (Arquivo do IFB).

${ }^{40}$ Congresso de Folclore. Inaugurado no Instituto Feminino o Museu de Arte Popular, A Tarde, 04.07.1957.

${ }^{41}$ Agremiação fundada em 20 de agosto de 1920, de finalidades filantrópicas e auxiliar da mulher que trabalha fora do lar, fundou restaurante, a Primeira Escola Comercial feminina e nos anos de 1950 o pensionato para moças. Etnicidade e ImigraçãolColeção Memória da SAARA Impressos\Igreja e Instituições. Associação de Senhoras Brasileiras, Rio de Janeiro, 1990.

Disponível http://docvirt.com/docreader.net/DocReader.aspx?bib=arq_cultura\&pagfis=25575. Acesso 10.05 .2020

${ }^{42}$ Marieta Alves estudiosa da Arte e autora de textos sobre o assunto, declara que conheceu Henriqueta Catharino em 1909, e dela foi amiga "até a morte" (ALVES, 2003, p.18)

${ }^{43}$ Museu de Arte Popular do Instituto Feminino da Bahia texto para enviar ao $1^{\circ}$. Congresso Nacional de Museus em Ouro Preto (julho de 1956). Datilografado com nota explicativa no final "Trabalho escrito por D. Marieta Alves, historiadora e $1^{\text {a }}$. secretária do IFB. Data: 18/09/1957." Arquivo do IFB.

${ }^{44}$ Os folcloristas se empenharam em pesquisas em vários estados brasileiros, formar coleções e museus. Cita-se a título de exemplo: José Augusto Garcez, Felte Bezerra, Bráulio do Nascimento, com exposições museológicas no período de 1948 a 1976 em Sergipe (SOUZA, 2019); Mário de Andrade (SP) embora não se visse como folclorista formou ampla coleção (COLEÇÃO MÁRIO DE ANDRADE, 2004) e criou em São Paulo a Sociedade de Etnografia e Folclore cujo Boletim definia os objetivos da agremiação: pesquisas de folclore e etnográficas em trabalho "realmente científico", seguindo as Instruções e Questionários resultando nas "cartas folclóricas" apresentadas no Congresso Internacional de Folclore por Nicanor Miranda em Paris, 1937 (SOARES,1983, p.7-12). Vale notar que o tema folclore teve em 1928, o I Congresso Internacional de Arte Popular (Praga), promovido pelo Instituto Internacional de Cooperação Internacional (IICI, criado em 1926 em Paris), órgão da Liga das Nações.

${ }^{45}$ Informe que pode ser lido em Museu Regional de Arte Antiga, O Imparcial - 24.09.1938 ( Álbum Recordando, p.161 - Arquivo IFB).

46 Sobre Ernesto Simões Filho consultar verbete em https://cpdoc.fgv.br/producao/dossies/AEraVargas2/biografias/Ernesto_Simoes_Filho. Acesso 09.05.2020

${ }^{47}$ Museu de Arte Popular do Instituto Feminino da Bahia texto para enviar ao $1^{\circ}$. Congresso Nacional de Museus em Ouro Preto (julho de 1956). Datilografado com nota explicativa no 
final "Trabalho escrito por D. Marieta Alves, historiadora e $1^{\mathrm{a}}$. secretária do IFB. Data: 18/09/1957." Arquivo do IFB.

48 Ofertado na década de 60 pela familia Orleans e Bragança. Consta que foi usado pela Princesa Isabel para prestar juramento como Regente do Império, em 1871 e para assinar a Lei Áurea em 1888.

${ }^{49}$ Instituto Feminino da Bahia Mostra Arte na Festa dos 50 Anos (Imagem digitalizada de CD fornecido pela Biblioteca do IFB). Sobre a obra de Waldete Cristina consultar: PASSOS, Ilma Vilasbôas. A Bahia oitocentista em Pano: representações em uma exposição. 155p. 2014. Dissertação. (Mestrado em Artes Visuais). Escola de Belas Artes, Universidade Federal da Bahia.

${ }^{50}$ Ressalta-se, aqui, que não tivemos até então acesso a documentação oficial que permita tal quantificação.

${ }^{51}$ Bahia: palavra mágica e manancial folclórico. A Tarde, 29.09.1956 (Album Recordando, p.282, Arquivo IFB).

52 "Fundação do Instituto Feminino da Bahia" - papel timbrado da Bahiatursa, 1974, assinado por Lúcia Marques, com a notação 033.11 (814.21) Fund. Inst. Femin. da Bahia BHA - e carimbo da Biblioteca Margarida Costa Pinto, no. 2867 (Arquivo do IFB), pg11-14.

${ }^{53}$ FREIRE, Luiz Alberto Ribeiro; HERNANDEZ, Maria Hermínia Oliveira (orgs.).

Dicionário Manuel Querino de arte na Bahia. Salvador: EBA-UFBA: CAHL-UFRB: 2014. 